Information Management and Business Review

Vol. 4, No. 6, pp. 332-339, June 2012 (ISSN 2220-3796)

\title{
Accepting of E-banking among Banking Customers of Pakistan
}

\author{
Muhammad Muazzam Mughal, Muhammad Farhan, Kamran Ali, Abdul Jabbar Khan* \\ University of the Punjab, Lahore, Pakistan \\ *abduljabbarkhan.hcc.pu.edu.pk@gmail.com
}

\begin{abstract}
E-banking is a platform through which a banking customer can perform its financial or non financial transactions electronically without visiting bank, which not only reduces transaction costs but also saves time.E-banking customers are increasing worldwide but its adoption is low in Pakistan. This study is done to investigate the most important factors which contribute to the espousal of E-banking in Pakistan. For this research primary data was collected from 217 customers of different ages, data was collected by structured questionnaire. Statistical descriptive analysis was used to analyze the data. The results shows that privacy and security, trust, ease of usefulness, knowledge and awareness, inaccessibility and came in person preferences are the factors which affect adoption of E-banking in Pakistani customers. Findings also indicate that banking customers of Pakistan are willing to take on E-banking if proper guideline and awareness is provided to them by banks or banking regularity authorities.
\end{abstract}

Keywords: E-banking, Pakistani banking customer, online banking, Pakistan

\section{Introduction}

Internet banking means that the customer is using the Internet to access their bank account and to perform banking transactions (Dixit \& Datta, 2010). Traditionally internet banking refers to development of a web page by a bank to provide basic information relating to its services and products. Presently the word "internet bankingincludesprovision of amenities such as accessing accounts, transferring funds, and buying financial products or services online" (Dixit \& Datta, 2010).This is an era of banking as everyone is directly or indirectly associated with banks or has to interact with banks either for any financial or non financial transactions. If we talk about traditional banking, customer has to go to banking premises within banking timings to perform their desired tasks or to get any financial or non financial information. Sometimes customers have to face a lot of difficulties to perform their tasks and it also wastes their time, energy and money as well.Through internet banking a customer can not only get thorough information about his account but about other banking products very easily by using computer or any other electronic device. In this modern age customer has no time to waste in long processes of ordinary banking transactions; internet banking has made it very easy to do it. It gives us golden chance to have access to our accounts every moment, all the time and everywhere. We are not confined to take this change at any specific place; we can have it any where we want whether at home or at workplace. Keeping in view the several advantages of internet banking, all banks are providing this facility to their customers. The time has gone when people were bound to perform their banking transactions only in restrictedterritory.E-banking has started a new era and now banking customers are not bound to any restricted territory,they can perform their transactions beyond limits.The evolution of E-banking started in early 1980s'. The basis of E-banking belongs to home banking which was through telephones and fax machines as computer and internet were not developed as much," Online services started in New York in 1981 when four of the city's major banks (Citibank, Chase Manhattan, Chemical and Manufacturers Hanover) offered home banking services" (Cronin, 1997).The bank of Scotland was the first bank who offered online banking services for the very first time for the banking customers of Nottingham Building Society in 1983.(http://www.thenottingham.com/about-us/our-proudhistory)[Retrieved 2007-12-14]. "Stanford Federal Credit Union was the first financial institution to offer online internet banking services to all of its members in October 1994"

Traditional banking in Pakistan has been replaced very effectively by Electronic banking by delivering ATMs, debit and credit cards, internet banking, phone banking and online products etc. In Pakistan, E-banking was firstly introduced by overseas banks in late 1990's and the concept was followed by domestic banks 
thereafter in the shape of ATM's and credit cards (Kaleem and Ahmed 2008). The delayed entry in electronic banking is well explained by The SBP Annual Report (2003); According to this report, delayed entry was due to controlling problems, highestablishingexpenses, continuingfinancial sector reforms and the absence of practical skills. In order to cope with the recent technical development of the world, Almost every Pakistani commercial banks has joined any one ATM switch network (currently two ATM switch networks i.e. one link and M-net) and has established its own ATM network and issuing its own debit and credit cards (Kaleem and Ahmed 2008). Above all, to facilitate the customer, every commercial bank in Pakistan has introduced its own website providing its customer to operate online and avail E- banking facility at any time.Despite a lot of benefits, the Pakistani customers are still following traditional banking channels rather than E-banking channels. Pakistani banking customers still prefer branch banking as they prefer to go to branch for their financial and non financial transactions rather than doing all this on few clicks. It is observed that educated customers even bankers themselves are not adopting E-banking services.The basic purpose of this study is to findout the factors which contribute towards low adoption of E-banking services in Pakistan and to highlight the factors which must be improved in order to increase the acceptance of electronic banking in Pakistan. The literature review of thestudy is discussed in Section 2 which clarifies the supportive elements. Section 3 relates to the research hypothesis. Section 4 describes methodology of the study and section 5 clarifies the empirical findings and discussion about the findings. Last segment relates to recommendations and conclusions of the study.

\section{Literature Review}

Internet based electronic banking applications are expanding in the recent years (Liao \& Cheung, 2003). According to Beckett, Hewer \& Howcroft (2000) latest technology has established very competitive market environment for banking service providers. However, in current scenario banks have needed to understand consumers' needs due to the changed competitive market conditions. E Banking is proposing its banking customers with a varied range of facilitated services now customerscanaccess their banking financial recordsand make financial or non-financial transactions effectivelyfrom everywhere without any time limits (Dixit \& Datta, 2010).

Electronic Banking: Electronic banking phenomena can be described in different ways (Daniel, 1999). Internet banking is a mixture of numerous delivery channels (Pikkarainen et al., 2004). According to Daniel (1999) E-banking is providing the customers their banking information via diversified delivery channels that can be accessedthrough different technological devices i.e. a computer or a cell phone with built in browser utility or telephone or any other digital technology. Electronic banking is usually known as internet banking or e-banking, in many ways e-banking is different from traditional banking because it uses different delivery channels and the decision to adopt e-banking is dependent on different factors (Dixit and Datta 2010). Mattilaet al. (2003) stresses that internet banking success dependent on customer satisfaction and banks will have to use different media to customize products and services to fulfill customers' specific present and future needs.Various researchers have gone through from the banking and adoption of internet banking issues in banking sectors. Various researchers have given various reasons. The main agreed upon reasons of not adopting internet banking is security and privacy (Kaleem and Ahmed, 2008; Siu and Mou, 2005); ease of usefulness of the internet banking (Davis, 1989; Manzano, Navarre, Mafe' Sanz-Blas, 2008); knowledge and awareness (Dixit and Datta 2010; Sohail and Shanmugham, 2004; Fitzergerald, 2004)

Security, Privacy andTrust: Worldwide fame of the advantages of E-banking has engrossed the concentration of several researchers now days internet banking is studied in various angels like perception of employees as well as customers regarding benefits and gains of E-banking and this has gained much importance in recent past (Kaleem and Ahmed 2008). Where E-banking has made our life very easy and has brought many benefits with it yet thing which is considerable with it is the cost associated with it ,Although ebanking has thousands of benefits yet banks should not ignores risks associated with it (Dixit and Datta 2010). Before going towards any transformation, banks must assure theappropriatemanagement of online banking threat (Al-Alawi, 2004). This is as complicated as to reach at moon for the customers as well as banks to establish the paramountloom to use of online banking (Dixit and Datta 2010). As there is a risk connected while trying to incorporatefresh channels with old channels (Aljlfri et. al., 2003). Chung and Paynter (2002) declared after their survey that a consumer has a fear regarding transaction safety as an obstacle to the 
acceptance of electronic banking. Thorton Consulting (1996) brings forth the reality that limited security is one of the supremehindrances on the way to the growth in the number of users of E-banking. Security has also been acknowledged as a main consumer distress in other internet banking acceptance studies (Siuand Mou, 2005). Trust is the most important persona on the stage of the internet banking. Trust has a very important role to play in internet banking and it is almost impossible to examine it as a phenomenon and very much complicated to contradict it in the framework of electronic commerce because of the difficulty and hazard of E-commerce and trust will be the crucialfeature for successor collapse of e-businesses (Dixit and Datta 2010).

Ease of Use and usefulness: Perceived ease of use (PEOU) is a main key to success in influencing customer's attitude towards the use of an effective information system (Jahangir and Begum, 2008). Davis (1989) introduced the technology acceptance model to describe the recognition of information technology and according to this model perceived ease of use and perceived usefulness are main contributors that are contributing to recognize a latest electronic delivery control. This technology acceptance model may be used to forecast online banking acceptance (Pikkarainen et al., 2004). We can define Perceived ease of use as "the degree to which a person believes that using a particular system would be free of effort",In this modern age people want ease and comfort, ease and facility is just like water for thirsty crow so any service or facility perceived to be easier to use than another is more likely to be accepted by users (Davis, 1989).The two basic fundamentals of information system acceptance are, perceived uselessness and perceived ease of the use, are illuminated by Davis (1989) as we know that the word "usefulness" means beneficial, advantageous, gainful, profitable and helpful so the phrase "perceived usefulness" means to consider, think, believe, judge, deem , estimate and suppose usefulness. In a way this phrase can be defined as "the degree to which a consumer believes that the use of a system will increase his or her performance", exclusively, it refers to efficacy at work, implicit efficiency as time saving and the comparativesignificance of the configuration for the individual's work. Now a days due to busy routine, no one is ready to put any effort in seeking something so "perceived ease of use" lets customer believe that he does not need any effort to put in order to use system, with effort being understood to include both physical and mental effort, and how easy it is to learn to use the system, In to the bargain, perceived ease of use influences perceived usefulness (Davis, 1989). In this advanced age people are wise enough to select an application that, theyperceive, will help them in their performance(Aderonke, Charles, 2010). Perceived usefulness is defined by Devis in these words that "the degree to which a person believes that using a particular system would enhance his or her job performance". earlierstudy on distance banking acceptancedescribes the fact of significant control of perceived ease of use on definite usage (Eriksson et al., 2005; Pallister et al., 2007) or internet and mobile banking services usage intention cannot be denied either directly or indirectly through its impact on perceived usefulness (Luarn and Lin, 2005). Internet banking web sites require ease in learning and use an ease in usage and learning appeals the attention of people or users, In order to perform their financial transactions and enhance their productivity of the banking activities, people prefer to have way to online banking as this is very easy means to fulfill their purpose (Manzano et al.,2008).

Knowledge / Awareness: In this time of science and technology, people want to take benefits of technology as its significance cannot be ignored but only hurdle in the use of technology is "lack of knowledge" (Dixit and Datta 2010). Sohail and Shanmugham (2004) puts forth the evidence of benefits of E-banking by reporting in a paper concerning about Malaysian customer's preferences in online bankingaccording to them access to the internet, knowledge of E-banking and customers' confrontation to transformare basically the contributing factors to adopt electronic banking. Major 'non adoption' areas are the safetyfears and lack of consciousness of electronic banking (Fitzergerald, 2004).

Inaccessibility: Inaccessibility as the major factor and cause of non adoption of e-banking. According to them inaccessibility means "No PC/No connection, slow internet connection, PC specifications prevent access. "Access to the internet is one of the most important factors that contribute to the acceptance of electronic banking channels (Sohail and Shanmugham, 2004).

Research Gap: Literature review indicates that most of the studies relating to of E-banking issues are in countries like Australia (Sathye, 1999), Malaysia (Sohail and Shanmugham 2004), India (Dixit and Datta 2010), and Saudi Arabia (Sohail and Shaikh, 2007) etc. As far as Pakistan is concerned we don't find too much 
work on internet banking or E-banking issues. This study is done to identify the causes affecting the customers' acceptance regarding the use of internet banking. An effort has been done to highlight the factors which are very important for all banks to increase or sustain their internet banking customer's portfolio.

Research Hypotheses: It is very important to highlight the reality that the Pakistani culture is poles apart from those countries where the earlierstudy was conducted on the E-banking issues. And as I mentioned in my literature review most of them have highlighted main issues which I hypothesize along with an additional issue which prevails in Pakistan that is came in service preferences which means a person has knowledge and access to banking products and services yet he is preferring branch or traditional banking.

Therefore, the resultinghypotheses are;

H1. Security and privacy influence the acceptance of E- banking among banking customers.

H2. Trust influences the acceptance of E- banking among banking customers.

H3. Ease of Use influences the acceptance of E- banking among banking customers

H4. Ease of Usefulness influences the acceptance of E- banking among banking customers.

H5. Knowledge and awareness influence the acceptance of E- banking among banking customers.

H6.Inaccessibility and came in service preferences influence the acceptance of E- banking among banking customers.

\section{Methodology}

A structured questionnaire was developed for the survey (data collection) which was consisting of 31 questions from the respondents about theirconsent for E-banking. This questionnaire was focused on the extent to which customers use the e-banking, their preferences while using banking products and services. Respondents were also asked if their banks are providing them guidance and sufficient support which is required for efficient e-banking usage.Customers of all major banks (all those banks which are providing efficient e-banking service) were focused in this study by simple random sampling technique.Structured questionnaire was used as a survey instrument for this study. The questionnaire was made in a way that helps to measure the impact of independent variables on adoption of e-banking services by the customers of Pakistan. The variables were measured using multiple items (different dimensions which contain questions on different elements). The scale items characterized in the assessmentinstrument are utilizing a five point liker scale.The anchors incorporated were $1=$ strongly disagree, ii) $2=$ disagree, iii) $3=$ neutral, iv) 4=agree, v) $5=$ strongly agree.The data was obtained from customers of banks from different cities of Pakistan on simple random sampling basis. The total numbers of questionnaires were 300 and useable responses were 217 i.e. $72 \%$.

\section{Results}

Demographic analysis: Table-1 shows all demographical factors about respondents of the study. The table shows that most of the respondents were of the age group 18-29 years of age (61.8\% of respondents). While considering the gender of the respondents we see that majority of the respondents were Male (79.7\%) and rest was Females (20.3\%). Both the genders represent a good strength of the banking customers as there are less female customers as compared to male so 20.3 percent female respondents represent good strength.While looking at the Qualification of the respondents, majority of the respondents were Master degree holders (65.9\%), the second most important strength was $27.6 \%$ which was represented by those customers who were having bachelor degree. It was interesting to see that (4.2\%) respondents were those who were intermediate or below intermediate. Only $2.3 \%$ customers were of Chartered Accountants and Ph.D.'s.While looking at the computer literacy it is clear that most of the respondents were computer experts $(62.2 \%)$. When we consider transaction method preferred by the customers we can clearly see that they prefer ATM transactions (59.9\%) and meanwhile this lead to online withdrawals which are (61.3\%). This means online banking transactions are mostly concerned with only withdrawals as far as respondents are concerned as this is clear that (41.9\%) respondents said they are using online banking to perform less than 10 percent of their total banking transactions. 
Table 1: Statistics of Respondents on demographic factors basis

\begin{tabular}{|c|c|c|c|}
\hline & & Frequency & Percentage \\
\hline \multirow{2}{*}{ Age } & $18-29$ & 134 & 61.8 \\
\hline & $30-39$ & 63 & 29.0 \\
\hline \multirow{5}{*}{ Gender } & $40-49$ & 15 & 6.9 \\
\hline & Above 50 & 5 & 2.3 \\
\hline & Male & 173 & 79.7 \\
\hline & Female & 44 & 20.3 \\
\hline & Below metric & 3 & 1.4 \\
\hline \multirow[t]{4}{*}{ Qualification } & Intermediate & 6 & 2.8 \\
\hline & Graduate & 60 & 27.6 \\
\hline & Masters & 143 & 65.9 \\
\hline & Others & 5 & 2.3 \\
\hline \multirow{3}{*}{ Computer Literacy } & Experts & 135 & 62.2 \\
\hline & Beginners & 42 & 19.4 \\
\hline & Average & 40 & 18.4 \\
\hline \multirow{5}{*}{ ction Method } & ATM's & 130 & 59.9 \\
\hline & Visit's Branches & 32 & 14.7 \\
\hline & Online Banking & 52 & 24.0 \\
\hline & Telephone & 3 & 1.4 \\
\hline & $<10 \%$ & 91 & 41.9 \\
\hline \multirow{5}{*}{$\begin{array}{l}\text { Percentage of online } \\
\text { Transactions }\end{array}$} & $10 \%$ & 40 & 18.4 \\
\hline & $20 \%$ & 31 & 14.3 \\
\hline & $>20 \%$ & 55 & 25.3 \\
\hline & Withdrawals & 133 & 61.3 \\
\hline & Funds Transfer & 57 & 26.3 \\
\hline \multirow[t]{2}{*}{ Online services } & Utility Bills payment & 22 & 10.1 \\
\hline & Others & 5 & 2.3 \\
\hline
\end{tabular}

Descriptive Analysis: Discussion along with results: This table indicates the mean and standard deviation score of independent variables (security privacy, trust, ease of use, usefulness, knowledge awareness, inaccessibility and came in preferences,). In this regard five point Likert scale was used to get the responses of the customers.From the table we can see that security and privacy, trust, usefulness knowledge and awareness, and inaccessibility and came in person preferences have tendency towards score 4 which means agree response. These statistics indicates that as far as adoption of E-banking is concerned customers are very much concerned with the security and privacy issues and trust on these E-banking channels, they are willing to adopt E-banking or want to continue with the existing E-banking channels if banks ensure them 
about the security and privacy issues as well as banks insure them that all their financial and non financial information will remain secure. Result $\mathrm{H} 1$ and $\mathrm{H} 2$ accepted.

Table 2: Descriptive Statistics

\begin{tabular}{lll}
\hline Items & Mean & Std. deviation \\
\hline Security privacy & 3.5372 & .58721 \\
Trust & 3.5061 & .64706 \\
Ease of use & 3.2719 & .37345 \\
Usefulness & 3.9113 & .75762 \\
Knowledge awareness & 3.6106 & .78681 \\
Inaccessibility & 3.5507 & .74828 \\
\hline
\end{tabular}

Secondly we can see from statistics that means secure of usefulness is highest as compared to any other variable which indicates customers are highly concerned and agree with the views that they will use ebanking channels or will continue using existing e-banking channels if these channels are really useful for them in all respects. Customers are cost and time sensitive and they are willing to adopt E-banking channels if these channels or facilities really facilitates them or useful for them. Result H4 accepted.Thirdly statistics indicates that knowledge and awareness has second highest mean score which indicates that customers will adopt E-banking if they have sufficient knowledge to use them or get benefit from them and secondly in this regard they will use-banking if they are aware of these channels or financial and non financial facilities which they can get out of it. Result H5 accepted.Fourthly statistics indicates that inaccessibility and came in person preferences do have tendency towards 4 (agree), which indicates that E-banking usage has direct link with the access of these E-banking channels, customers will use these channels if they have proper access of computer, internet or other channels or mechanism which bridges the customers with E-banking. Other thing which is very important is come in person preferences, if the customers do have accessibility to E-banking channels there will be less came in person preferences. Result H6 accepted.Lastly statistics show that mean score of Ease of use is near to 3 which mean neutral, which indicates customers are neutral in this regards if these channels are easy to use or not, they will be willing to use E-banking in all respect provided that all their other concerns which have been discussed above are considered. Result H3 is not accepted.

\section{Conclusion and Recommendations}

- Banks should ensure to the customers that their websites are secure for financial transactions because this is the main concern of the customers they do believe that their adoption of e-banking is based on the financial security and confidentiality which banks are providing in branch banking or traditional banking.

- Banks have customers who don't possess computers or internet or both banks should make outlets booths where computers are available and customers can operate banking websites any time any where just like ATM booths this will also encourage those customers to be a loyal e banking customers who don't possess computer or internet.

- Banks should also motivate the customers how e-banking is useful for them for this Banks should arrange seminars to educate the customers on e-banking usage, banks should educate the customers how e-banking can save their time and cost through electronic and print media. Like people can be educated that they can access their account and perform any financial and non financial transaction any where any time.

- Bank's staff should also guide the customers and provide them useful tips to use e-banking as most of the customers are not aware of all the electronic financial and non financial facilities. Bank's staff should educate the customers how they can accomplish their task effectively and efficiently by using E-banking.

- Banks website and ATM machine's graphical user interface should be very user friendly as customers use electronic services only if these services are not complicated, complex and uneasy, customers can be attracted towards e-banking by making these clear, comprehensive, convenient, efficient and user friendly. 
- Educated customers want innovations as they are innovative in nature they are ready to adopt Ebanking if banks motivate them. Organization is required to segment the market and then focus on theirs pacific needs and preference. (Dixit and Datta 2010).

Furthermore banks should be very careful about their online banking system that customer's don't face any difficulty while operating their account online because even only one bad experience may result in customer's discontinuation from E-banking services (Jun \&Cai, 2001).like banks should be careful that funds are transferred in time through online channels ATM's always remain in order banking websites don't create any problem while accessing them online etc.Customers do want to adopt E-banking if they are guaranteed about the security and privacy issues trust about their issues, they are provided knowledge and awareness about issues and they are given all the facilities relating to E-banking use. In a country like Pakistan where people are not very much educated and don't know the use and usefulness of e banking there is a need to provide a better and customized service to themhere state bank should play its role. State bank of Pakistan should force banks to arrange seminars, to advertise regularly, trains staff about E-banking issues so that a common customer gets benefits from E-banking.Lastly customers should also be educated that online banking does not only mean only withdrawals there are many other very beneficial facilities (financial or non-financial) as this study indicates that customers who are using E-banking 61.3 percent uses it only for withdrawals.

Limitations and Scope of Further Research: As there has been no comprehensive research has been conducted in Pakistan which is focused on adoption of E-banking, this is an initial step to explore the customer's perception on E-banking use.

- In this study educated people of working environments were part of sample it did not include those customers who are not much educated or those who don't know the usage of computer or internet or other e-banking devices.

- Sample of 217 people was focused in this study. Future research requires a larger sample for more accurate results.

- The respondents of the survey were from cities of Pakistan but this research did not focus on small towns where there is good literacy rate. Further research requires a comprehensive focus of small towns and even those villages where ATM machines are available.

Further research is required to investigate the issues that how banks can enhance customer's satisfaction and loyalty with respect to E-banking while working on these strategies banks can enhance their e-banking customer portfolio.

\section{References}

Aderonke, A. A. \& Charles, A. K. (2010). An Empirical Investigation of the Level of Users' Acceptance of EBanking in Nigeria. Journal of Internet Banking and Commerce, 15(1).

Al-Alawi, A. I. (2004). Customer Relationship Management in the Kingdom of Bahrain. Issues in Information Systems, IACIS, 5(2), 380-386.

Aljlfri, H. A., Pons, A. \& Collins, D. (2003). Global e-commerce: a framework for understanding and overcoming the trust barrier. Information Management \& Computer Security, 11(3), 130-138.

Beckett, A., Hewer, P. \& Howcroft, B. (2000). An exposition of consumer behaviour in the financial services industry. The International Journal of Bank Marketing, 18(1).

Chung, W. \& Paynter, J. (2002). An Evaluation of Internet Banking in New Zealand, in Proceedings of 35th Hawaii Conference in System Sciences (HICSS 2002), IEEE Society Press, 2002.

Daniel, E. (1999). Provision of electronic banking in the UK and the Republic of Ireland. International Journal of Bank Marketing, 17(2), 72-82.

Davis F. D. (1989). Perceived usefulness, perceived ease of use, and user acceptance of information technology. MIS Quarterly, 13(3), 318-39.

Dixit, N. \& Datta, S. K. (2010). Acceptance of E-banking among Adult Customers: An Empirical Investigation in India. Journal of Internet Banking and Commerce, 15(2).

Eriksson, K., Kerem, K. \& Nilsson, D. (2005. Consumer acceptance of internet banking in Estonia. International Journal of Bank Marketing, 23(2), 200-16. 
Fitzergelad, K. (2004). An Investigation into People's Perceptions of Online Banking[online]Availablefrom:http://staffweb.itsligo.ie/staff/eward/ebus200203/Discussion20topi cs/Online20Banking.htAccessed 7 March 2010].

Jahangir, N. \& Begum, N. (2008). The role of perceived usefulness, perceived ease of use, security and privacy, and customer attitude to engender customer adaptation in the context of electronic banking. African Journal of Business Management, 2(1), 032-040.

Jun, M. \&. Cai, S. (2001). The Key Determinants of Internet Banking Service Quality: A Content Analysis. International Journal of Bank Marketing, 19(7), 276-291.

Kaleem, A. \& Ahmed, S. (2008). Bankers' Perceptions of Electronic Banking in Pakistan. Journal of Internet Banking and Commerce, 13(1).

Liao, Z. \& Cheung, M. T. (2002). Internet based e-banking and consumer attitudes: An empirical study. Information and Management, 39, 283-295.

Luarn, P. \& Lin, H. H. (2005). Toward and understanding of the behavioral intention to use mobile banking. Computers in Human Behaviour, 21(6), 873-91.

Manzano, A. J., Manzano, C. L., Ruiz-Mafe, C. \& Sanz-Blas, S. (2008). Key drivers of internet banking services use, www.emeraldinsight.com/1468-4527.htm

Mary, J. C. (1997). Banking and finance on the internet, john wiley and sons, Canada.

Mattila, M., Karjaluoto, H. \& Pento, T. (2003). Internet banking adoption among adultcustomers: early majority or laggards? Journal of Services Marketing, 17(5), 514-28.

Pikkarainen, T., Pikkarainen, K., Karjaluoto, H. \& Pahnila, S. (2004). Consumer acceptance of online banking: an extension of the technology acceptance model. Internet Research, 14(3), 224-35.

Sathye, M. (1999). Adoption of internet banking by Australian consumers: an empirical investigation. International Journal of Bank Marketing, 17(7), 324-34.

Sohail, M. \& Shanmugham, B. (2004). E banking and Customers' preferences in Malaysia: an empirical investigation. Information sciences, Informatics and Computer Science: an International journal, 150 (3-4), 207-217.

Siu, N. Y. M. \& Mou, J. C. W. (2005). Measuring Service Quality in Internet Banking: the Case of Hong Kong. Journal of International Consumer Marketing, 17(4), 97-114.

Thorton, C. (1996). Thorton consulting online banking: a success. Australian Banking and Finance, 5(13), 2. 